\title{
We Humbly Stood / Hami Binamra Ubhiyaun
}

\section{Bishwa Sigdel}

\section{We Humbly Stood}

In white canvas

You first stroked the paintbrush

We stood humbly

The way for the first drop of milk waits

the virgin bosom

Startled, a little inquisitive

Somewhere sweet affliction

Akin to inarticulate fear

That was how we stood

Swinging with heart full of curiosity and assurance

In a murky canvas

You stroked the paintbrush twice

We stood placidly

Contorted due to the weight of the spine since ages

We humbly stood

In the yellowish canvas

You stroked the paintbrush thrice

We stood quiet

If was a spinner would have spun in a moment 
The mind thousand whirls

If was a movable would have moved

The mind thousand miles

Flown if could have flown, burnt if could have burnt

But we maintained silence and

We humbly stood

Stroking the brush for the seventeenth times

Searching for white in the eighteenth times

And not obtaining it

You must think of us as adamant ones

Thinking, we humbly stood.

Poet- Bishwa Sigdel

-Translatted into English by Anjila Bista 


\section{हामी विनम्र उभियौं}

\section{-विश्व सिगदेल}

सेता क्यानभासमा

तिमीले पहिलो कुची चलायौ

हामी विनम्र उभियौँ

कुमारी छाती

जसरी गई प्रथम थोपा दूधको प्रतीक्षा

चकित-चकित, केही उत्सुकता

कता-कता मीठो पीडा

अव्यक्त डरजस्तो

यसरी नै हामी उभियौं

हृदयभरि उत्सुकता र भरोसाको खेल्दै पिड

मटमैलो क्यानभासमा

तिमीले दोस्रोचोटि कुची चलायौ

हामी चुपचाप उभियौं

सदियौँदेखिको ढाडको भारीले कुप्रिएका हामी

हामी विनम्र उभियौँ

पहेंलो-पहैंलो क्यानभासमा

तिमीले तेस्रोचोटि कुची चलायौ

हामी मौन उभियौं

घुम्ने चिज भए घुम्यो पलमा

हजार फन्का मगज

गुड्ने चिज भए गुड्यो पलमा

हजार कोस मगज

उड्ने भए उड्यो, डड्ने भए डढ्यो

तर हामीले धारण गयौं मौनता

हामी विनम्र उभियौं

सत्रौं पटक कुची नचाएर

अठारौं पटकमा क्यानभास सेतै खोज्नु

र नपाउनुबिच

तिमीले के कति मानौला हामीलाई अटेरी

सोच्दे हामी विनम्र उभियौं। 


\section{Author Biography}

Bishwa Sigdel, a noted poet, lyricist, and critic, is one of the literary figures in contemporary poetry from Banepa, Nepal. He recently just published his first poetry collection, entitled 'Sociology of Applause'. His poetry has appeared in journals and magazines like Drunken Boat (USA), Grey Sparrow (USA), Between These Shores (UK), Eternal Snow (India) and Divine Madness (Volumes 3 \& 5, Adrus Publications, Canada). However, Obsession (2013, Red Ink, India), a joint anthology of stories, is his most appreciated contribution, which reflects his versatility and brilliant knack for storytelling.

\section{Translator Biography}

Anjila Bista is a dedicated academic who has been passionately involved in the field of education for the last 2 decades. Born and raised in Lalitpur, Nepal, she is a Delhi University graduate who enjoys reading, singing, and enjoying life as it comes. She has an uncanny ability to inhale the beauty that lies in between the lines of any work of literature. She believes that the knowledge and perspective that her reading gives her has strengthened her skills to a level where she can now express her thoughts while also playing with her words. 